\title{
TAMAN SISWA AND THE INDONESIAN NATIONAL AWAKENING
}

\author{
Ruth T. McVey
}

Adjustment to foreign-imposed change is both difficult and humiliating, and the early response of the Javanese elite to European conquest was to save what they could by denying the foreigners culturally while conceding to them politically. This reaction brought a flowering of Javanese high culture, but it also made that style of life seem increasingly remote and irrelevant to the problems of the time. By the late nineteenth century some people were beginning to urge accomodation to the alien system that, however unfamiliar and unpleasant, seemed to contain the future. They came, in this beginning period, from those members of the elite who were well enough placed to acquaint themselves with western culture and also sufficiently on the periphery of the traditional system to be able to consider the old order with some detachment and to find profit in its modification. These advocates were to be found first of all among the bupati (regents) of what had been the outer lands of the realm, whose desire to maximize freedom from the political-cultural center encouraged an openness to outside ideas and a predeliction for the role of mediator. The "progressive" bupati were naturally from among the more intellectually daring of that class, and above all they represented its younger generation, whose vision of the world was set by exposure to western education, by a greater consciousness of European penetration, and by a more acute realization of the decay of the traditional order than had prevailed when their fathers' view of life had been formed.

For the progressive bupati at the end of the nineteenth century, the essential problems were to break through the barriers to acquiring western-style education and to determine which European intellectual habits the Indonesians could most usefully adopt. The following generation found, however, that so much of the indigenous culture had become obsolete that it could scarcely be expected to provide the framework for a coherent way of life. The ferment attendant on this discovery gave rise to the national movement, an effort to create an identity that was simultaneously modern and indigenous. The most conscious and public manifestation of this movement was political and aimed at the achievement of independence, but, for ali its importance, this was only one aspect of a larger movement for cultural transformation.

The basic assumption of the national movement, that the foreign challenge could only be met in terms of its own style, placed it very much nearer the pole of westernization than of traditionalism; in a sense the emphasis on national character 
was a coating that made palatable an otherwise bitter cultural pill. It was not a dose swallowed without misgivings, and in some cases it was not really taken in at all; but the fact was that the goal of a modern Indonesia had ideological hegemony over the natinnal movement, and those who gave this ideal only the barest lip service were still making a formidable cultural concession in acknowledging that this was the aim that ought to be pursued.

The group that first proposed such a drastic reorganization of the Indonesian world view was drawn, as the previous generation of ideological innovators had been, from the younger members of that elite segment best situated to take advantage of European education and of a revision of the traditional order. By the time the Budi Utomo was founded, in the first decade of the twentieth century, this position had been assumed by the lower prijaji, who took advantage of the developing westernstyle school system to offset their relatively humble birth by a knowledge of Dutch language and methods. Succeeding years found new groups brought to the border zone between the traditional and modern colonial cultures, as improving education and communications, the development of the bureaucratic apparatus and the modern economy, and the decay of the indigenous social hierarchy created "new men," the half-educated, and the culturally dispossessed in ever broader strata of society, involving the population in an ideological revolution that is still going on.

Just as the progressive bupati, ideological innovators of their own generation, were found over-cautious by those of the next, so the Budi Utomo was criticized for timidity by its successors, as the deepening cultural crisis and the passage of initiative to the less well born increased the insecurity of the innovating groups and the radicalism of their response to the pressures of change. This double contrast, between younger and older generations as well as between social groups, was to be a continuing theme in the development of the national movement and in post-revolutionary Indonesian society. It has meant that within any given social group there is likely to be a sharp generational difference of approach, so much so that there is often more understanding between two social groups of the same generation than between the older and younger members of the same group.

Although the national movement chose the modern over the traditional order, its inner history was not one of steady progress from a lesser to a greater degree of westernization. For one thing, as larger groups became involved in the national awakening, people with only a rudimentary exposure to western schooling became influential in it as spokesmen or clientele, and the movement accordingly reflected their lesser familiarity with and usually greater ambivalence toward western ways. Moreover, with the fading of initial optimism regarding the compatibility of Indonesian and Dutch interests and the ease with which 
modernity could be achieved, a reaction set in which led to the modification or rejection of many of the uncritically westernizing assumptions of the national movement, though never its basic thrust. More important perhaps, the national movement had several areas of concern, and individuals or groups that favored radical innovation in one of them might well be conservative in another. Participants in the movement conceived and related cultural adaptation, foreign rule, and social change in very different ways, so that it is nearly always misleading to consider the development of the national movement or even of its individual components solely in linear terms of right and left, radical and conservative.

It is also difficult to sort the ideological concepts put forth by the national movement according to whether they were traditional or modern in origin and thrust. For one thing, in a transitional period the most creative ideas tend to come from the confluence of traditional and modern thought and it is impossible to credit the one or the other exclusively. We can trace the Taman Siswa idea, if we wish, from Suwardi Surjaningrat's Netherlands exile of 1913-17, when he obtained a teaching certificate, attended the First Colonial Education Congress in The Hague, and participated in discussions regarding a "national" modification of the Indies school system, a subject of some debate among Dutch educators at the time. ${ }^{1}$ We can find its origins equally well in a culturally traditional group, the Pagujuban Selasa-Kliwon, which met under the well-known Jogjakarta mystic Pangeran Surjamataram to discuss questions of Javanese mysticism (kebatinan). It decided that what Indonesia needed most was a good national education, and when one of its members, Suwardi, succeeded in founding the first Taman Siswa school, the group disbanded on the grounds that its ideal had been realized,

1. The question of a modification of the Indies educational system arose as the result of a reaction by both radicals and conservatives against Ethically-inspired emphasis on instruction along wholly western lines. This began in Dutch educational circles about 1915, but was not reflected in the Indies itself until several years later, when it formed the basis of the "rational Ethical" approach praised by Ki Hadjar Dewantara in the following article. See I. J. Brugmans, Geschiedenis van het onderwijs in Nederlandsch-Indië (Groningen, Batavia: J. B. Wolters, 1938), PP. 348-356. For a contemporary account of the debate, see Jan Anne Jonkman, Indonesisch-Nationale grondslag van het onderwijs ten dienste der Inlandsche bevolking (Utrecht: P. den Boer, 1918). For an account of Suwardi Surjaningrat's speech to the First Colonial Education Congress in 1916, see Abdurrachman Surjomihardjo, "An Analysis of Suwardi Surjaningrat's Ideals and National-Revolutionary Actions (1913-1922)," Madjelis Ilmu-ilmu Sastra Indonesia (II, 3), October 1964, Pp. 390-39I. 
various of its members thereupon forming the institute's first board of governors. ${ }^{2}$

Taman Siswa's kebatinan background marked it as on the abangan side of Java's great cultural cleavage; ${ }^{3}$ it could in some ways be considered the abangan counterpart of the Muhammadijah school system, which was a decade old at the time of its founding. The two associations were the most important Indonesian-run educational systems during the colonial period. Both were initiated by leaders of the pioneer organization of

2. See Ki Hadjar Dewantara, Dari Kebangunan Nasional Sampai Proklamasi Kemerdekaan (DJakarta: Endang, n.d. Lforeword 1952J), P. 65; Ki Hadjar Dewantara, Demokrasi dan Leiderschap (Jogjakarta: Madjelis Luhur Taman Siswa, n.d. [foreword (959), P. 7; S. Mangoensarkoro, "Het nationalisme in de Taman Siswa-beweging," Koloniale Studiën (XXI), 1937, p. 293; Sajoga, "Riwajat Perdjuangan Taman-siswa 1922-1952," in Taman Siswa 30 Tahun (Jogjakarta: Madjelis Luhur Taman Siswa, n.d. [foreword 1952]), pP. 193-194. Surjamataram's teaching was Ilmu Begdjo, the science of happiness, and the slogan of the Selasa-Kliwon ( $\mathrm{Sa}-\mathrm{Ka}$ ) group was "for the happiness of self, of nation, of mankind." It met every Tuesday that fell on the Javanese market-day Kliwon to discuss the achieving of this aim. The leader of the Selasa Kliwon adepts was R. M. Sutatmo Surjokusumo, a Buddhist and leader of the "radical" faction of the Budi Utomo; he became first chairman of the Taman Siswa governing board. R. M. H. Surjoputro, another Selasa Kliwon member, became vice-chairman, and B. R. $M$. Subono, Sutopo Wonobojo, and Pronowidigdo, all members of the kebatinan group, were members. Not surprisingly, Dutch references to the Taman Siswa almost invariably give Suwardi's Netherlands experience as the origin, while the Taman Siswa's own accounts prefer the Selasa-Kliwon source.

3. Between the santri (pious Muslim) and abangan ("agama Djawa") communities; see Clifford Geertz, The Religion of Java (Glencoe: The Free Press, 1960). The orientation of the Taman Siswa toward pre-Islamic forms is evident in the terms it chose for its levels of study and teachings. See Ki Hadjar Dewantara, "Nomenclatuur dalam Pendidikan Kebangsaan," Poesara (IV, 3), Dec. 1933; in Karja Ki Hadjar Dewantara (Jogjakarta: Madjelis Luhur Persatuan Taman Siswa, 1962) (I), pp. 114-117. Apparently aware of this, Ki Hadjar pointed out that the Taman Siswa used some Arabic-derived words too ( $p$. 117). According to Abdurrachman ( $p .396$ ), the Jogja Resident Jonquière made use of this contrast in his initial efforts against the Taman Siswa, warning local Muslims that the association was "atheist" and "anti-Islam." 
the national movement, the Budi Utomo. ${ }^{4}$ Both had their center in Jogjakarta and their strength very largely on Java; ${ }^{5}$ and both represented attempts at combatting oldfashioned ways and educating Indonesia for the modern world. Of the two systems, the Muhammadijah was considerably larger and more prosperous. It could count on the ideological fervor and relative affluence of its modernist Muslim clientele, who were mostly from the indigenous urban commercial class; moreover, the Indies government gave it a rather generous subsidy, since the schooling it provided generally met Dutch standards and the authorities were interested in channelling Islamic energies into nonpolitical activities. 6

The approaches of the Muhammadijah and Taman Siswa to education in a changing world were quite different, in part because of the specific reasons for their foundation. The Muhammadijah was established in 1912 to promote the cause of modernist Islam in the Indies and also to compete with the increasingly aggressive Christian missions as a source of modern education. It was not so concerned to establish a system that reflected the native Indonesian character; on the contrary, in a reaction akin to that which created Protestantism in Europe, Islamic modernism

4. Akira Nagazumi, "The Origin and the Earlier Years of the Budi Utomo, 1908-1918" (Ph.D. dissertation, Cornell University, 1967), pp. 150-152; Deliar Noer, "The Rise and Development of the Modernist Muslim Movement in Indonesia During the Dutch Colonial Period, 1900-1942"' (Ph.D. dissertation, Cornell University, 1963) (I), Pp. 115-132.

5. In Sumatra, the principal modernist Islamic educational system was the Sumatera Thawalib. A Sumatran Taman Siswa equivalent was Moh. Sjafei's Ruang Pendidik, or Indonesisch Nationale School (INS). Sjafei was a teacher at the Kartini school in Batavia who went to Holland in 1922 to study teaching methods and thereafter headed a school in Kaju Tanam, West Sumatra. He attempted, through stress on self-expression and on physical and artistic as well as mental endeavor, to implant selfconfidence in the students so that they would not seek service with the foreigners but would become self-employed. See Muhamad Said, Ilmu Mendidik Nasional (Jogjakarta: Pertjetakan Republik Indonesia, n.d. [foreword 1955]), pp. 63, 137; Sutedjo Bradjanagara, Sedjarah Pendidikan Indonesia (Jogjakarta, n.p., $1956)$, p. 92 .

6. Government subsidies comprised a considerable proportion of the Muhammadijah's income; a breakdown of its central budget for 1929 shows that of a total income of $f 164,089.01$, $f 83,251.94$ came from a colonial government subsidy and $f 6,290.60$ from the sultanate. Mededeelingen der Regeering omtrent enkele onderwerpen van algemeen belang (Juni 1930) (Weltevreden: Landsdrukkerij, 1930), cols. 53-54. This did not all relate to education, as the Muhammadijah engaged in a number of social welfare and religious propaganda activities. 
sought to rid the religion of local accretions that were contrary to its original teachings and helped prevent Muslim societies from adjusting to the demands of the changing times. Consequently, the Muhammadijah made no attempt to invoke the spirit of the pesantren; the traditional Muslim center of learning; its schools offered a curriculum equivalent to that of the colonial school system, with religious instruction in addition. This approach was, needless to say, an abomination to the traditionalist Muslim teachers, who saw in the Muhammadijah system the first step on the road to secularization; and they may have been right, in the sense that the flow of Indonesian Islam has been toward the modernist approach and at the same time toward secularism.7

The Taman Siswa educational effort was conceived quite differently. In the first place, coming ten years later than the Muhammadijah, it was a reaction to disappointment in the fruits of western-style education as much as it was an attempt to make that schooling available to the Indonesian public. Suwardi surjaningrat (he took the name Ki Hadjar Dewantara in 1928) was able to take advantage of criticisms of educational methods then being made in western countries to help define his discontent at the colonial approach to teaching and to develop a style that could be considered progressive in international terms as well as characteristically Indonesian. The Taman Siswa's founder made use particularly of the ideas of Montessori and Frobbel in Europe and the Dalton school system in the United States, with their stress on self-expression, the adjustment of teaching to the terms of the child's world, and the techniques of indirect guidance and control. Rabindranath Tagore's criticisms of western education and his Santiniketan school were also much admired by $\mathrm{Ki}$ Hadjar and his associates, though, like other leaders of the Indonesian national movement, they never rejected western ways to the extent Tagore and Gandhi did.8

7. For a description of an attempt to marry the pesantren tradition with modern education, and observations on recent trends in the kolot-modèren conflict in Javanese Islam, see Lance Castles, "Notes on the Islamic School at Gontor," Indonesia (I, 1), April 1966, Pp. 30-45.

8. For Ki Hadjar Dewantara's analysis of these foreign approaches, see his "Tentang Frobbel dan Methodenja," Poesara (XI, 5), May 194I, Karja (I), PP. 249-255; and "Dr. Maria Montessori Pengandjur Pendidikan Merdeka," Poesara (XIV, 5), Sept. 1952, Karja, pp. 265-273. Ki Hadjar related that he had first become acquainted with Tagore's writings in 1913 through their Dutch translation by Frederik van Eden and through Noto Soeroto's Rabindranath Tagore's opvoedingsidealen (Amsterdam: Hadi Poestaka, n.d.) (see "Hubungan Kita Dengan Dr. Tagore," Poesara [XI, 8], August 1941, pp. 131-134). Tagore visited the Taman Siswa school in Jogja in 1927; after that a fairly regular contact was maintained with Santiniketan, and some Taman Siswa students went there to study. Montessori visited the Taman Siswa school in 1940. 
The Taman Siswa founders were not challenged ideologically by the traditional school system as the Muslim modernists were; they could instead find in it principles of use in building a system that was modern but uniquely their own. Moreover, because the abangan ethos was not reflected in an organized body of doctrine but expressed in a style of life, it was not possible to arrive at the Muhammadijah's compromise and give a secular curriculum plus instruction in the faith. 9 Instead, the abangan spirit was made to pervade the entire program of study, the organization of the school, and the method of teaching. If it can be said to have concentrated in any field, it was in that of the arts, which were stressed both in Ki Hadjar Dewantara's pedagogical theories and in Taman Siswa practice. Engagement in Javanese music, dance, and visual art were seen as giving the pupils a sense of their own culture and also enabling them to express themselves spontaneously; and out of this confluence of custom and creativity came a significant contribution to the development of modern Indonesian art. I0 The Taman Siswa did not meet the colonial government's standards, as it did not follow the prescribed curriculum--indeed, it did without government subsidy in order not to adhere to that schedule and to demonstrate that Indonesians were capable of providing for themselves. But the Jogjakarta Taman Siswa school provided an excellent education for its time, and the system as a whole showed great creativity both in its conception and in its execution by those who participated in it.11

9. The Taman Siswa schools left their members freedom of religious and political belief and taught formal religion only as comparative ethical systems. Ki Hadjar Dewantara urged that the republican government schools do likewise, and, reflecting the abangan fear of a santri-imposed religious Gleichschaltung, stressed that the greatest possible leeway for religious divergence must be allowed (speech to the AllIndonesian Education Congress, October 1949: "Pengadjaran Agama Dalam Sekolah," in Abito Marto Hardjono, Adjar dan Dasar [Djakarta: Widjaja, 1951], pp. 73-75; and see also Ki Hadjar Dewantara, Pantjasila [Jogjakarta: Usaha Penerbitan Indonesia, 1950], pp. 18-22). The Taman Siswa was periodically attacked for this attitude as "atheist," though Taman Siswa supporters argued that the pervading influence of the abangan ethos made the schools religious though not sectarian (S. Mangoensarkoro, "Het nationalisme . . .," P. 295).

10. See Claire Holt, Art in Indonesia (Ithaca: Connell University Press, 1967), p. 195. For Ki Hadjar's theories on ant in education, see Karja (I), pp. 301-365, esp. "Dasar-dasar Umum dan Garis-garis Besar Pendidikan Kesenian di Taman Siswa," Pusara (XVI, 3/4/5), Karja, June/July/August 1954, pp. 353-365.

11. For comment on the level of Taman Siswa teaching, see Mededeelingen... 1930, cols. 45-46. According to this source, about 70 percent of Taman Siswa primary school graduates passed government examinations for clerk, or for 
The contrast between the Taman Siswa and Muhammadijah systems illustrates several difficulties that arise in discussing the problem of transition from what is traditional to what is modern. We can, for example, argue that the education provided by Muhammadijah was more modern than the Taman Siswa's because Muhammadijah schooling more closely followed the European model and did not seek to approximate an idealized past. Conversely, it can be maintained that because the Taman siswa was able to adopt a critical attitude toward the colonial educational system and to concern itself with the cultural and psychological background of the children it taught, its approach was very modern by international as well as Indonesian standards. The advantages that may be gained from coming later are that one can avoid one's predecessors' mistakes and skip unnecessary stages; should one therefore accept profferred patterns uncritically? It may be argued that they are easier to copy and therefore more quickly transferred if taken over as they stand; it may be replied that by the same token they are likely to be more remote from the society to which they must be fitted and harder for its people to comprehend. Some, conscious of lost time and fearful the country might never catch up to modernity's receding image, might urge that the most modern ideas and methods must be imposed; others might feel that anything that was itself very modern in style was less likely to have a modernizing effect on the society than something less radically different from the society's own experience. These questions admit no easy answers, but participants in the national movement had to deal with them in nearly all matters of cultural adaptation.

At the turn of the century the modern and the traditional formed generally discrete and easily identifiable cultures, but soon thereafter this ceased to be the case. Modernity began to assume various shapes, not simply that of western Europe and America: Japan, Turkey, Soviet Russia, and later China came to proffer their own roads to the future. Moreover, as Indonesian society adopted forms which were no longer of the traditional culture, a semantic difficulty arose. Is something modern if it is of the present, a response to changing times? Or must we insist on the teleological concept of modernity favored by the development-minded and implicit in the national movement's decision to strive for a "modern" Indonesia: namely that those things are modern which contribute to a society's ability to provide for its members' wellbeing--and in particular their material wellbeing--in the world of our times? If the latter, how are we to classify responses which are neither traditional,

entrance to intermediate or trade schools, but most went on to study at the Taman Siswa intermediate or teacher training schools. Of the intermediate school (Mulo) students thus far graduated by the Taman Siswa, a little less than half had passed the examination for government senior high school (AMS), which was not a bad score giving the highly pyramided character of the Indies educational system. 
nor, from the point of view of achieving modernity, constructive? And how is one to judge what will in the end bring society nearer to that goal and what will merely lead it astray? So much depends on the observer's angle of vision, and, since what is apprehended as modern tends to be that which corresponds to one's own experience or predelictions, it is very possible for people writing at different times or from different ideological assumptions to arrive at very different conclusions as to what represents a step towards modernity and what does not. When we consider that the participants in the Indonesian national movement were faced with the same ambiguities, and that for them it was not a matter of academic classification but the fate of their society and their personal lives, we can gain some idea of the great psychological tension which the transition from traditional culture involved.

It is perhaps as much because of this strain as by reason of traditional concepts of the good life that harmony was so strongly stressed as a goal of the national movement. When modernity was achieved, when the foreigners were removed, when the national self was realized, then things would at last fall into place, and one would know where one stood in the world and why. Meanwhile, to show the way and to make bearable the present disorder, patterns and concepts should be introduced which symbolized the longed-for state of rest. In the Taman Siswa's official philosophy, the association was seen as a "spiritual family," of which Ki Hadjar Dewantara was the father and the system's founding principles the mother. 12 When in 1930 considerations of control and the implementation of the Taman Siswa's educational principles made it necessary to give the system a regular organizational structure, every effort was made to preserve the familial concept and the idea of paternal leadership.

12. Ki Hadjar Dewantara, in Demokrasi dan Leiderschap, pp. 1112, defined the Taman Siswa family relationship as reflecting the origin of "keluarga"--family--in the words kawula and warga. '" Kawula' means a 'servant,' whose duty is to subordinate himself and devote all his strength to the one he views as his 'Master.' Warga, on the other hand, means 'member,' who bears responsibility and who has the authority to take part in management, and to guide and oversee performance." See also S. Mangoensarkoro, "Leidende gedachten bij het z.g. amongsysteem van de Taman Siswa-scholen," Koloniale Studiën (XXII), 1938, pP. 595-608; S. A. Soedibjo, "Sedikit Tentang Organisasi Taman-Siswa," Taman Siswa 30 Tahun, pp. 167-169. The text of the founding principles can be found in Sajoga, pp. 195-198. Their essence was the Pantja Dharma--natural law, culture, independence, nationality, humanity (Kodrat-alam, Kebudajaan, Kemerdekaan, Kebangsaan, Kemanusiaan); this formula was provided by the Selasa-Kliwon group (Ki Hadjar Dewantara, Azas-azas dan Dasar-dasar TamanSiswa [Jogjakarta: Madjelis Luhur Taman Siswa, 1952], pp. 67). With the revolution, independence was moved up to first place. 
As General Leader of the association, Ki Hadjar held the right of "dictatorship"--that is, of imposing his decision, subject to the custom of the group and its future consensus, in cases where a crisis threatened or disagreement could not be overcome. For the western concept of majority rule, "the tyranny of half plus one," was contrary to the family sense of unity, where the voice of the least must be taken into account and responsible subordination to the wisdom of the family head was the necessary condition for harmony. Therefore there must be democracy with leadership--demokrasi dan leiderschap--so that the interests of all might be served without disrupting peace and order. 13

The organization of a group, or of the state and society, on a "family basis" has been a continuing theme in modern Indonesian thought. It has served to justify paternalism in government and social relations--the much-condemned bapakism--and to discourage internal challenges to leadership; but these have been results of the concept rather than its origins. In part its ideological prominence rests on its basis in traditional ideas of the good society and of the proper relationship between the people and those who govern them. In part, too, it appears to reflect a sense of alienation similar to that voiced by the European critics of the commercial and industrial revolutions. Society, in this view, is no longer an organism; it has become a machine, functioning for some alien purpose, cold to the needs of its members, who have become cogs spinning meaninglessly on the axis of self-interest. The traditional social hierarchy no longer has meaning, the new forms as they stand are unendurable; what remains is the family, regret for an idealized past, and the sense of a mortal need for community.

The result of this malaise in Indonesia was the creation of associations and of social concepts that utilized modern organizational forms and served the general goal of achieving a modern Indonesia, but that "nationalized" these forms by giving them an ideological content that would restore the lost sense of community. Moreover, as the active participants in the national movement generaliy shared the sense of fraternity of those willing to suffer for a cause, it was not hard for them to envisage ideals of solidarity and voluntary subordination as capable of becoming general social rules. Once the sense of being endangered was past and the goal of independence achieved this feeling quickly dissipated, producing a pervading sense of disorientation and loss, and later bringing attempts to regain unity and purpose through the symbolic reincarnation of the revolution.

13. Ki Hadjar Dewantara claimed this concept was authored by $R$. Sutatmo Surjokusumo, who introduced it about 1919 at a meeting of the Selasa-Kliwon group in which the subject of democracy and its limitations was discussed (Demokrasi dan Leiderschap, pp. 6-8). 
Related to the ideas of harmony and community was the concept of the People. With the breakdown in authority of the traditional social hierarchy, the as sumption by socially lower groups of the innovating role in the Indonesian national movement, and the consequent rejection of the superior orders as "feudal," the whole legitimacy of the social ranking system was brought into question. Because the upper classes tended to be more conservative regarding the question of independence, and because the more cosmopolitan of their members used the Dutch language and European manners, the nationalists (though themselves often Dutch-speaking) came to view them as corrupted, no longer the bearers of indigenous culture. As it became apparent that independence had to be forced from the reluctant Dutch, the matter of appearing to have mass backing behind one became increasingly important to the politically ambitious. And finally, ideas of popular government and social equality received from outside as the claimed prerequisites for modernity and nationhood acted to increase the importance of the common people in the calculations of the emerging Indonesian national elite.

These influences combined with older concepts of the good society and with the deeply felt need for community to produce the idea of the People as legitimating principle--the Rakjat, people in the sense of both folk and mass. The People was envisaged as the unspoiled bearer of the culture, the hope for purification and the restoration of a naturally ordained just society. In this translation of tradition, the court was replaced by the village as the valid cultural center; the approval of the People became necessary to the legitimacy of government, the popular welfare was the touchstone of a regime's success, and the maintenance of unity between the People and those who lead them was a matter of central concern. The population may in fact have been seldom consulted, before or after the revolution; but that does not negate the ultimate importance of the ideological position any more than the lack of actual modernization makes insignificant the fact that modernity was accepted as the national goal.

On the one hand, nationalist sentiment viewed the village as the reservoir of Indonesian culture; on the other, the transformation of the villager was seen as a major goal of modern nationhood. The common man was still ignorant (masih bodoh); he must be made literate and educated in his duties as a citizen; then and only then would he understand (baru insjaf). His awareness was not viewed as transforming village society; rather, it was seen as restoring and purifying it. For if a natural harmony is to be found anywhere, it is in the village, the cradle of the national culture; its present degeneracy and ineffectiveness can be overcome by making the people conscious (bikin sadar), and in this way the basis will also be created for a society which possesses both the spiritual oneness of the past and the knowledge that will enable it to take its place in 
the modern world. This hope inspired the national movement's efforts at popular education, of which Taman Siswa was one; ${ }^{14}$ and it provided the drive for the literacy campaign that was Indonesia's great accomplishment in the first decade of independence.

The vision of the naturally harmonious village was, of course, the elite's view of the common mass. There was contradiction enough in it, but prior to independence very few stopped to consider whether education or new farming techniques might not carry village society away from all tradition; or that the changes that had already been wrought in village life were neither wounds to be healed nor impurities to be removed, but cumulative and permanent transformations. The discovery that the People were a source of contradiction, self-seeking, and conflict was a hard and bitter one, and most of those who struggled for independence preferred not to make it--not simply out of

14. Popular enlightenment was not the sole purpose of the national movement's educational effort, as the emerging national elite devoted considerable energy to improving educational opportunities for its own social group. At the 1908 Budi Utomo congress this was a major subject of argument, with the majority urging "education from above"--chiefly by way of opening European education opportunities for the lower prijaji--on the argument that the elite's knowledge would eventually trickle down to the populace; a radical minority led by sutomo and Tjipto and Gunawan Mangunkusumo argued unsuccessfully for "education from below" (Nagazumi, pp. 82-86). Soon afterwards the minority approach gained ascendancy, partly as a result of the radicalization of the national movement and partly because of the example set by the Muhammadijah, which observed no class distinctions in its service to the ummat. The long-term tendency in the national movement was toward a bifurcation between efforts aimed at progressively higher education for the leaders' social group and projects aimed at developing practical skills and social consciousness among the masses. The PNI displayed both these trends well: on the one hand it sponsored a fund to support Indonesian students pursuing advanced studies abroad, and on the other it established a People's School (Perguruan Rakjat). The latter, begun in Batavia in 1928 by Moh. Nazif, Arnold Mononutu, Moh. Yamin, Sartono, M. H. Thamrin, and other well-known nationalists, adopted a statement of principles implicitly opposed to the Taman Siswa's esthetic and quietist approach: "We wish to avoid vague philosophizing over deep abstractions and transcendental concepts which do not relate to real life; we wish instead to show the Indonesian that he must direct all his emotion and thought to answering the concrete problems of his society," (quoted in Mededeelingen...1930, cols. 48-49; see also J. F. H. Alb. de la Court, Paedogogische richtlijnen voor Indonesië [Deventer: $W$. van Hoeve, 1945], pp. 57-58). The spiritual descendant of this approach in more recent times was the PKI's Universitas Rakjat (UNRA) system. 
economic interest, but because it took away the hope for internal peace which had been so much a goal of their effort. And if the fact were accepted, what was one to do? To tear the society apart and rebuild it utterly? This is a task which very few have cared to contemplate; even those who urged social revolution have not in general seen it this way. Instead, they carried the idea of impurity a step further: for them it was not only the foreign-connected elite that had become denatured but all those who could be said to have wealth.

This radical interpretation was immanent in ideas long current in the national movement. It was not the paternally governing lurah, the pious and industrious hadji, or the wise village elder who was set forth as the example of the noble commoner, but the man without authority or wealth: Pak Marhaen, Pak Krama, Wong Tjilik, the symbols of the virtuous poor. Cultural particularism and social egalitarianism went hand-in-hand in the nationalism of the colonial period, the latter achieving expression chiefly in romantic gestures on the part of an elite that could not quite conceive of actually being on equal terms with the common man. There were movements to speak only one level of Javanese, to dress in the common style, to drop the use of titles and of aristocratically long names, and so on. In the Taman Siswa the principle of kerakjatan, People-mindedness, was raised to an essential of indigenous culture; while at the peak of the association's cultural nationalism campaign, at its April 1936 congress, Ki Hadjar Dewantara called on Taman Siswa members to drop all distinctions and call each other saudara seperguruan--brothers in learning. 15 There was no thought of class conflict in all this, and if we wish to speak of it in terms of traditional and modern, then it surely looked toward an idealized past rather than a modern future. Nonetheless, it played a vital role in making modern--and particularly Marxist--theories of social transformation ideologically acceptable in Indonesia; the two streams, nativist and foreignderived, fused to form a powerful radical current which neither would probably have been capable of producing alone. 16

15. S. Mangoensarkoro, "Het nationalisme...," p. 292. On the same lines, no distinction was allowed between those who taught in primary and secondary schools in prestige or claims on money and equipment (Soedibjo, p. 174). This rule, which was somewhat relaxed after independence, affected an area that has been a major source of tension within the Indonesian educational system. The stress on simplicity and egalitarianism relates to traditional ascetic ideals; thus Ki Hadjar Dewantara pointed out that a senior teacher (called hadjar or pendeta in the Taman Siswa system) should amass no personal or family wealth, but must free himself from private property in order to increase the level of his spiritual power ("Nomenclatuur . . ," p. 115-116).

16. An unconscious illustration of this convergence is provided in Ki Hadjar Dewantara's description of the origin of his 
As the national movement spread beyond the circle of gentlemen who had initiated it to the broader and lower reaches of society, personal leadership became increasingly important as a mediating and shaping influence. It was not uncommon for the wellborn maverick to become a revolutionary leader, for a radically-inclined politician of the older generation to take up the cause of the young turks, or for a highly educated leader to make the illiterate mass his clientele. The authority which such a person of superior status lent to the group he adopted usually increased considerably its power of popular attraction and also made it more readily accepted as salonfähig by the core leadership of the national movement, which remained in elite hands. Moreover, the social standing and habit of authority of such patrons meant that they rarely were figureheads; more likely than not, such a leader exercised a great deal of influence in shaping the public personality of his group, and as he and his following were of socially or generationally different background a certain distortion in the presentation of its outlook was thus likely to occur. The latent tension this produced usually surfaced in the course of time, most often in the form of'a younger generation protesting what it held to be arbitrary and old-fashioned leadership, while the leader and his close associates grew increasingly concerned to prevent the group's falling into the hands of upstarts who did not comprehend the purity of its endeavor.

The Taman Siswa provided a good example of this sort of leadership in Ki Hadjar Dewantara. He was born R. M. Suwardi Surjaningrat in 1889, of the Jogjakarta lesser royal house of Paku Alaman. He took considerable pride in his high birth, 17

concept of "democracy with leadership." He ascribed the leadership principle to $R$. Sutatmo Surjokusumo and the principle of kerakjatan to Mas Marco Kartodikromo's idea of "sama rata, sama rasa." Outside of the polarity of their political affiliations--Sutatmo was a member of the Volksraad for the Budi Utomo, Marco was a Communist who died in the Digul concentration camp--the two displayed great differences in their cultural ties. Sutatmo was a cultural conservative whose radicalism in his early years as Budi Utomo. leader sprang more from a distrust of uncritical westernization than from a desire to see Indonesia modernized. Marco was much more a "modern man" in the sense of being culturally uprooted and uncertain. He began as a strong Muslim, became a secular nationalist journalist who defended Suwardi Surjaningrat and the other Indische Partij leaders at the time of their exile, went to Holland himself, and returned to become a Communist.

17. He wrote a book on the intellectual endeavors of members of the royal house: Ki Hadjar Dewantara, Beoefening van letteren en kunst in het Pakoe-Alamsche geslacht (Djokja: H. Buning, 1931). The Javanese royal houses have at various times made themselves centers of ferment, and at the time Suwardi 
which did not prevent him from making an early career as one of Indonesia's first revolutionaries; in 1913 he was sent into exile in Holland as one of the leaders of the strongly anticolonial Indische Partij. By the time he founded the Taman Siswa school system in 1922, he had abandoned much of his political rebelliousness as the product of youth and over-optimism and instead stressed the "principle of acceptance" of enforced change, which he declared must be responded to cautiously but positively. But because his efforts were devoted to an educational system aimed at the general mass of the population and not just the elite, his following tended to be considerably younger, lower in social status, and politically more radical than he. 18

The central leadership of the Taman Siswa during the colonial period consisted in the main of those who were associated with Ki Hadjar Dewantara in founding the system and tended thus to be of the older generation and of relatively high social standing. The governing boards of the Taman Siswa branches were more mixed politically and socially, consisting of some wellborn persons who sought to preserve Javanese culture against indiscriminate westernization, people who were politically inactive but who hoped to increase the availability of modern education for Indonesian youth, and people who saw cultural nationalism and modern education as important weapons in the struggle to free the country from foreign rule. Some of the Taman Siswa instructors were nationalist politicians interested in supplementing an uncertain income, furthering the cause of Indonesian progress, or obtaining a public reputation. Very few of the teachers had the educational, political, and social qualifications that would give them a comfortable alternative in government service, the preferred occupation of the nonsantri middle class.

Surjaningrat became politically active the Paku Alaman was so engaged. Suwardi's elder brother, R. M. Surjopranoto, was a theosophist and revolutionary who, among other things, compiled an encyclopedia whose serial issues were confiscated by the police on the grounds that they explained socialism and Communism. He began a movement, Adidarma, intended as an "army of labor," which would help the People by setting up schools, legal aid offices, polyclinics, small credit facilities, and so on; and he also established a union of sugar workers whose initial success in confronting the colonial establishment gave him lasting fame as Indonesia's "strike king."

18. "A further fact: although the Taman Siswa people were free in their political and religious convictions, of those who entered political parties 95 percent if not all entered parties which were nationalist and indeed 'leftist'--at that time the PNI or PI [Partindo]; and if they entered a religious party they also chose one which was to the 'left.' The same for the students; a great part entered the Pemuda Indonesia, 
It is questionable how well many of those who taught in the Taman Siswa schools outside Jogjakarta were qualified to follow Ki Hadjar's particular philosophy of instruction. For the first eight years of the Taman Siswa's existence it is certain that very few were, for only the loosest ties of experience and authority bound the other schools to the Jogja center. The early Taman Siswa was less a system than an agglomeration of schools, some with previous affiliations to other groups, which placed themselves under the general sponsorship of the movement in Jogjakarta. The main school in Jogja had itself been acquired from another association, Surjopranoto's Adidarma Educational Institute, which in failing had bequeathed to $\mathrm{Ki}$ Hadjar

Dewantara its equipment and its students.19 A number of Budi Utomo-sponsored schools placed themselves under the Taman Siswa wing, as did some of the Sarekat Islam schools and the Communists' Sekolah Rakjat. 20

and after it was absorbed into Indonesia Muda they joined the latter's 'left' wing" (Sajoga, p. 216).

19. Although Adidarma was established to aid the masses, its school originated in an elite concern, the 1914 decision of the Dutch government to open the new Dutch-Native schools (HIS) only to children from the highest classes. This aroused a considerable reaction among the lesser prijaji (see Robert Van Niel, The Emergence of the Modern Indonesian Elite [The Hague, Bandung: W. van Hoeve, 1955], pp. 176-178), one of the results of which was the foundation of the Adidarma school as a private HIS in 1915. Suwardi Surjaningrat joined the board of the Adidarma institute on his return from Holland, and was the school's director at the time of its failure in 1922. See Abdurrachman, PP. 395-396; Ki Hadjar Dewantara, Dari Kebangunan. . ., p. 148; Sajoga, p. 191. One of the reasons for the horrified reaction to his new school which $\mathrm{Ki}$ Hadjar Dewantara describes in the following article is probably the expectation of Europeanstyle education created by its predecessor.

20. Although a number of Budi Utomo schools transferred to the Taman Siswa, the party continued to maintain some in Central and East Java, where they provided education on Dutch lines; see Mededeelingen. . . 1930, cols. 46 and 47 for a description. The Sarekat Islam schools largely came under the domination of that movement's left wing, as the Communist leader Tan Malaka, a teacher who had studied in Holland, made his Semarang SI school into a major influence in the system. For his educational theories, see Tan Malaka, S.I. Semarang dan Onderwijs (Semarang, November 1921). The "Red" SI schools made particularly rapid headway in West Java, with their principal center there in Bandung. In April 1924, following the schism that separated the Communists from the "White" Sarekat Islam, the leftist schools took the name sekolah Rakjat; the government persecution of the next few years 
The early "wild schools"--institutions functioning without government subsidy and approval--often acted as independent enterprises once they had got themselves established, moving from one sponsor to another as financial backing, government attitudes, and general popularity made this association or that more desirable as a patron. Once the Taman Siswa was well under way, schools which set themselves up in outlying areas sometimes proclaimed themselves part of the Taman Siswa system without having had any contact with Jogja beforehand. In general the schools outside Jogjakarta did not have their students in residence, though this was an important part of the Taman Siswa formula. Some stressed instruction in Dutch, contrary to the cardinal principle that the child should learn in his own language. Presumably this was a concession to the ambitions of the local parents, and perhaps to the conceit of the teacher, for in the Indies Dutch-language education ranked socially above that provided in the local tongue.21

From the government's point of view, the principal danger in this loose structure was that the Jogjakarta Taman Siswa was unable to enforce its ban on politics in the classroom on the other schools affiliated to it. Ki Hadjar and his associates were also concerned for this problem, particularly since the late $1920^{\prime} \mathrm{s}$ saw both a rapid growth of the Taman Siswa and a radical ferment among the younger generation of Indonesian intellectuals. The heightened nationalist feeling also increased the sense of a need for a truly Indonesian style of education, and so encouraged the decision to shift from the "emergency work" of supplying as much opportunity for education as possible to the "missionary work" of transmitting the Taman Siswa philosophy. For the latter, much greater control and contact with the outlying schools was required; and so in 1930 the first Taman Siswa congress was held and the grouping was transformed, at least on paper, into an association with modern organizational lines. 22 It is most

caused many to be handed over--or to go over--to other sponsorship to avoid harassment. The Bandung SR school was thus handed over to Sukarno, who in turn placed it in Taman Siswa hands (Sajoga, p. 194).

21. Mededeelingen .. 1930, cols. 45-46; and see S. Mangoensarkoro, "Het nationalisme . . .," pp. 289-290; and Sajoga, pp. 206-207, for criticisms of the early Taman Siswa schools and accounts of the decision to reorganize them.

22. At the head of the Taman Siswa were the General Leader, the central governing board (Madjelis Luhur), the Badan Pengetua, an advisory body consisting of those who had been associated in the founding of the association who were to see that its original ideals were lived up to. Schools outside Jogjakarta were run by branches, whose boards (madjelis tjabang) were entitled to send delegates to conferences called by the center; major branches were 
doubtful whether central control was ever very effective, but the reorganization did bring a change in emphasis in Taman Siswa activity, a decade of conferences and congresses which reflected greatly improved contact between Jogjakarta and the outlying schools, and a considerably greater adherence of the individual schools to the Taman Siswa philosophy of education.

The Taman Siswa also established its own teacher training system, the Taman Guru. ${ }^{3}$ Not all its graduates went on to teach at the Taman Siswa, but many did so at least for a time. There was a marked tendency for those who entered the Taman Siswa system to stay in it rather than to transfer out to government-sponsored schools, 24 and frequently those who had graduated from a Taman Siswa teacher training course had had all

also represented on the Madjelis Luhur. The highest electing and policy-making body was the congress (rapat besar). However, the only time balloting was used to elect officers was at the 1938 congress, where it was judged a failure: too many "orang luar" (outsiders) were nominated, and there were too many factions, so in the end the leadership had to present its own slate of acceptables (Sajoga, p. 237).

23. When the Taman Siswa began, it consisted of a primary school and a teacher training class, which was expanded in 1924 into a combination junior high school and teacher training school (Mulo-Kweekschool). In 1926 this upper segment divided into a separate intermediate school and a teacher training school. The full system consisted of Taman Indrija (kindergarten); Taman Anak (primary school, grades 1-3); Taman Muda (grades 4-6); Taman Dewasa (junior high); and Taman Dewasa Raya and Taman Madya (senior high schools). The Taman Guru took graduates of the Taman Muda; there was also a Taman Guru Indrija for girls who wished to teach kindergarten. The Taman Dewasa Raja primarily educated those who would later teach at Taman Dewasa. The Taman Madya, the last of these schools to be formed, reflected a Taman Siswa response to the growing interest in sociallyoriented education remarked in note 15. It had two divisions, one to prepare for further academic work and the other a "social" one, giving training in the arts of journalism, advising the People (volksconsulschap), leading organizations, commerce, art, literature, etc.; it was hoped that students would be able to serve internships in various enterprises and organizations in the course of their study (Ki Hadjar Dewantara, "Taman-Madya," Poesara [XI, 7], August 1941, in Karja [I], pp. 128-131). For a description of the formal structure of the Taman Siswa schools, see Wardojo, "Sedikit Tentang Organisasi Perguruan," Taman Siswa 30 Tahun, pp. 176182. The Taman Siswa's hope to establish its own university-Taman Ilmu--was never realized.

24. Mededeelingen...1930, cols. 45-46. 
their schooling in that system. These teachers, particularly if they had studied at the Jogjakarta school, were naturally well versed in the Taman Siswa's educational philosophy and techniques, and if they worked in outlying schools could do a good deal to keep them functioning in the spirit of Ki Hadjar. They did not always follow the Jogjakarta leadership on all points, however, particularly as their youth and social background inclined many of them to entertain revolutionary ideas.

Although a few members of the established elite sent their offspring to Taman Siswa schools out of anticolonial or culturally conservative convictions, the Taman Siswa clientele consisted mostly of upwardly mobile commoners, clerks and petty bureaucrats, who could not place their children in the limited number of government-run schools. 25 The families to which Taman Siswa teachers and students belonged were usually on the fringes of the group that had been drawn into the modern sector of colonial society, and it was quite unclear, especially during the Depression, which, if any, of such a family's members would succeed in attaching themselves firmly to the new elite and which would sink into the urban kampung mass. This precarious socio-economic environment, the combination of cultural nationalism and modern education which was the basis of the Taman Siswa system, and the presence of radical nationalists on the schools' teaching staffs and governing boards all made for the easy growth of revolutionary anticolonial sympathies in spite of the fact that politics were banned in principle from the Taman Siswa's classrooms and that its philosophy stressed "peace and order" as the cardinal social good.26

25. This had its effect during the mid-1930's, when the government granted an allowance to those of its employees who had their children in officially approved schools. Few could afford Taman Siswa education under those circumstances, and the loss of much of its paying clientele put the system in desperate straits; it argued, eventually with success, that allowances should be granted to parents irrespective of where their children studied. Another indication of the background and ambitions of the Taman Siswa members was the temporary collapse of the system at the time of the Japanese invasion, as students and teachers headed off to "merebut pangkat" and become, as they thought, officials in the new government. Sajoga, pp. 232,245 .

26. The "peace and order" (tertib-damai, tata-tentram) slogan was much approved by the Dutch, whose catchword for colonial rule was the same (rust en orde). It was adopted by the Taman Siswa in 1923 and abandoned in 1947 in favor of the more revolutionary "struggle" (perdjuangan). A Taman Siswa conference of 1930 forbade teachers to take part in the leading bodies of political organizations without special permission, this apparently to minimize Taman Siswa implication in radical nationalist activities. For an expression 
The fact that those Taman Siswa participants who were politically active tended to be more radical than either the principal sponsors or the ideology of their institution can be seen in the extent to which the latest eddies in the nationalist current were reflected in the Taman siswa conventions, particularly at the 1932 congress, which took place in the wake of the schism that divided the radical nationalist movement into the Partindo and Pendidikan Nasional Indonesia. The meeting saw heated debates between the partisans of the two groups, which were strongly represented among the Taman Siswa members. "Swadeshi" clothes were the Partindo fashion of the moment, and that party's adherents appeared at the congress "looking exceedingly beggarish, with, for example, a pitji made of bamboo matting, badju and sarung of the cheapest local stuff, and not even sandals on their feet. The atmosphere at that time was very different from the congress of 1930; then they had worn good western clothes, clean and with a tie." 27 Most of the postrevolutionary politicians who had come from the Taman Siswa system found the PNI or PKI most sympathetic politically and culturally, though a few became prominent in the lesser secular organizations and one, Wali Al-Fatah, was to become active in Islamic politics. 28

Although the voice of the political radicals was heard loudly at the Taman Siswa conventions and influenced attitudes of those attending the schools, it received very little official recognition. For one thing, it would have been impractical to accord it overt attention in a time of conservative colonial rule; the Taman Siswa schools were harried enough by the authorities, in spite of the high praise that the Dutch also bestowed on them. 29 For another, Ki Hadjar Dewantara dominated

of Dutch concern on this score, see Mededeelingen . . . 1930, col. 46. The Japanese echoed this fear of agitation in their 1944 decision to close all secondary schools other than trade schools; accordingly the Taman Dewasa and Taman Guru shut down, not to reopen until the revolution was over.

27. Sajoga, P. 216 .

28. PNI leaders who had been active in the prewar Taman Siswa included Sarmidi Mangunsarkoro, Ali Sastroamidjojo, Sartono, and Wilopo. PKI leaders included Achmad Sumadi, S. A. Sudibjo, Njono, and Wikana. Moh. Tauchid became prominent in the PSI, and Sudijono Djojoprajitno and Sjamsu Harja Udaya were followers of Tan Malaka. In the late Guided Democracy period the PNI made an unsuccessful effort to gain control of the Taman Siswa, which it reckoned might serve as the base for a mass education network that could compete with the Communists' UNRA: it tried this mostly by working on disaffected members of the Taman Siswa younger generation.

29. Most of the Taman Siswa's battles with the government were fought in the $1930^{\prime} \mathrm{s}$. The 1932 regulation restricting "wild schools" provided the most specticular clash, but the most 
the official personality of the Taman Siswa almost completely. As the founder, guiding spirit, and General Leader of the association, he was accorded a very great respect, and his word was not questioned publicly, however much disagreement or disobedience his policies may have confronted in practice. The appointment and reshuffling of the central bodies of the Taman Siswa was very much in his hands, and although a gradual expansion of the membership of the governing board provided greater representation for outlying schools and other opinion, the guiding force remained that of the group associated with Ki Hadjar from the beginning. No bodies that developed within the Taman Siswa became effective alternative foci of opinion, though the Persatuan Pemuda Taman Siswa, the association's youth group, did come to display a somewhat distinctive personality and to involve itself in the broader affairs of the Indonesian youth movement of the $1930^{\prime} \mathrm{s} .30$

Some unease at $\mathrm{Ki}$ Hadjar Dewantara's officially unquestioned rule was sporadically evident within the Taman Siswa in the $1930^{\prime} \mathrm{s}$, but it was only in the postcolonial period that this seems to have become a problem of serious proportions. The Japanese occupation and the revolution disrupted the Taman Siswa organization, greatly reduced the number of those able and willing to serve on its staff, and created a crisis over the continued purpose of the system. ${ }^{31}$ This seems to have drained the movement

difficult period politically, in the Taman Siswa's estimate, was 1934-1936. Then many branches were closed and over sixty Taman Siswa leaders jailed in a campaign aimed at people who had had connections with the PNI or Partindo, hung Diponegoro's portrait on the wall, or were for other reasons thought subversive. For an account, see Sajoga, pp. 217-226.

30. The (Persatuan) Pemuda Taman Siswa emerged from the association of Taman Siswa secondary school students (Mulo-KweekschoolVereeniging Taman-Siswa, MKVTS), which began in 1927. It held its first conference in 1933, at which time it changed its name. It published a magazine, Suara Taman Siswa (later Sotya); one of its principal figures was the left revolutionary Ieader Sjamsu Harja Udaya.

31. The Taman Siswa entered the postrevolutionary period with an estimated 80 percent of its former staff gone; the number of its branches was 40 percent of that in the colonial period, but there were four times as many pupils as the largest prewar number (Sajoga, Pp. 245-246). During the revolution a major debate had taken place in the association as to whether, as some felt, the Taman Siswa's goal had been achieved and it should be disbanded; whether it should continue until the government was able to provide sufficient schooling on its own; whether it should maintain one or two of the best schools to set an example for Indonesian education; or whethen (as happened) it should continue more or less as before. 
of much of its vitality; and whereas the 1920's and 1930's had seen great innovation and energy on its part, the postrevolutionary years, for all the continued activity of $K i$ Hadjar and the sympathy of the republican government, saw little more than the continuation of policies laid down before the war. In consequence, the Taman Siswa began to acquire a somewhat fusty and provincial image, which led to a growing impatience among its senior|students and younger staff and did little to ease the critical problem of renewing its supply of trained and dedicated personnel. Ki Hadjar Dewantara died in 1959, and leadership passed to his wife and longtime associates. The problem of disaffection among the younger generation became greater with the passage of time and the absence of the man whose personality was so much a vital part of the system; but the Taman Siswa has continued to survive in spite of these difficulties and the economic and political pressures of the postrevolutionary period. Indeed, if its image has become slightly oldfashioned it has also become greatly respected as an example of simplicity and idealism retained in a corrupt age.

Ki Hadjar Dewantara wrote no major work on education, but he composed a number of essays explaining various aspects of the Taman Siswa approach. One of the most important, both as an elucidation of the Taman Siswa's method and an expression of the cultural crisis which the system was designed to meet, was an article titled "Een en ander over 'Nationaal Onderwijs' en het Instituut 'Taman Siswa' te Jogjakarta," which originally appeared in the Indisch Vrouwen-Jaarboek and was also issued as a pamphlet by the Taman Siswa in 1935.32 In 1938 it was

republished with minor changes and a rather lengthy introduction and postscript; this version may be found in the collected works of $\mathrm{K} i$ Hadjar Dewantara in both the original Dutch and an Indonesian translation. ${ }^{33}$ The editors of Indonesia have had prepared a translation of the article, which is presented in the following pages as an example of Ki Hadjar's contribution to the ideology of the Indonesian national awakening. The translation follows the original article of 1935; where changes of substance were made in the 1938 version, this has been noted. Unless otherwise indicated, the annotation is mine.

At the same time, a new set of principles was drawn up; see Ki Hadjar Dewantara, "Azas-azas . . ," pp. 45-64.

32. Ki Hadjar Dewantara, Een en ander over "Nationaal Onderwijs" en het Instituut "Taman Siswa" te Jogjakarta (Jogjakarta: Brochuren-Serie "Wasita," 1935). Wasita was originally the Taman Siswa journal, which began publication in 1928 and failed after two years; it continued as the publisher of Taman Siswa materials and tracts. A new magazine, Poesara was begun in 1931, and the association also began a more general magazine Keloearga, in 1936.

33. Ki Hadjar Dewantara, "Nationale Opvoeding," Brochuren-Serie "Wasita," 1938; in Karja (I), pp. 29-70. 